\title{
QUARTERLY ANALYSIS: THE PROGRESS OF MONETARY, BANKING AND PAYMENT SYSTEM, FIRST QUARTER - 2013
}

\section{Bank Indonesia Quarterly Report Team}

Indonesia's economy in the first quarter 2013 growth slowed compared to the previous quarter. Economic growth stood at $6.02 \%$ (yoy), lower than the previous quarter grew by $6.11 \%$ (yoy). A source of slowing growth came from domestic demand amid declining export performance. Slowing growth in household consumption was due to the decrease in purchasing power as a result of an increase in inflationary pressures, especially food. In addition, government consumption growth is relatively low, due to the limited uptake of spending, especially spending on goods. A decline also occurred in investment performance, particularly non-construction that is influenced by limited domestic and international demand outlook. Decline in investment performance is in line with the decline in business optimism. In non-construction investment, there is reduced performance in machinery investment, in line with the slowdown in the imports of capital goods. In contrast, exports showed improvement, supported by strengthening expectations of global economic recovery and rising volume of world trade. Response to slowing domestic demandsaw a contraction in imports. Sources of downward import pressure are from the imports of raw materials and capital goods, mainly raw materials for the industrial and passenger vehicle industry which has seen a slowdown and moderation in response to motor vehicle sales.

On the external side, the external balance of the economy has improved as expected. Current account deficit in the first quarter of 2013 stood at $2.4 \%$ of GDP, down from $3.5 \%$ of GDP in the previous quarter. Repair to the current account deficit is caused by the improvement of the balance of trade driven by a sharp decline in imports, particularly consumer goods, while non-oil exports of some commodities remained in positive growth. Meanwhile, capital accounts and financial (TMF) in the first quarter of 2013 recorded a deficit in line with the decline in capital inflows because of the deteriorating global economic conditions and rising inflationary pressures in the country. With these developments, international reserves at the end of March 2013 amounted to 104.8 billion U.S. dollars, which is equivalent to 5.7 months of imports and government foreign debt payments.

During the first quarter of 2013, the exchange rate was still experiencing downward pressure, although more moderate than the previous quarter. The moderate downward pressure was driven by inflows of foreign capital into the economy of Indonesia. In addition, the relatively moderate downward pressure was a result of the Bank Indonesia policy of maintaining the stability of the exchange rate in accordance with the fundamental conditions, through the 
strengthening of foreign exchange intervention mechanism, the application of term deposits (TD) and the deepening of the foreign exchange currency market. On the average, the exchange rate depreciated by $0.7 \%$ (qtq) to Rp.9.680 per U.S. dollar from Rp.9.613 to the U.S. dollar in the previous quarter. Meanwhile point-to-point, the rupiah depreciated $0.82 \%$ (qtq) and closed at Rp.9.718 per U.S. dollar. Despite this volatility, in the rupiah was still controlled. The rupiah's volatility is relatively lower when compared to the region.

Consumer Price Index (CPI) inflation increased on first quarter 2013 compared to the previous quarter, driven by rising prices of food groups. CPI inflation stood at $2.43 \%$ (qtq) or $5.90 \%$ (yoy), higher than the previous quarter at $0.78 \%$ (qtq) or $4.30 \%$ (yoy). The main source of inflation came from food volatility due to the limited supply of strategic food commodities, especially various spices and horticultural products. Meanwhile, core inflation was relatively stable despite the pressures of the food volatility. Stable core inflation was supported by the low pressure of the external factors due to slowing global commodity prices and exchange rate stability, balanced conditions for demand and supply, and subdued inflation expectations. Meanwhile, inflationary pressures from administered prices increased moderately due to an increase in the Electricity Tariff (TTL) on January 1, 2013.

Stability of the financial system and banking intermediation remains strong in the first quarter of 2013. Solid performance of the banking industry is reflected in the high capital adequacy ratio (CAR), which is well above the minimum $8 \%$, and the ratio of gross nonperforming loans (NPL) that was maintained fewer than 5\%. Meanwhile, credit growth slowed until the end of March 2013 to 22.2\% (yoy) in line with the slowdown in the domestic economy. Working capital and investment loans still showed high growth at $23.7 \%$ (yoy) and $23.2 \%$ (yoy), respectively. Meanwhile, consumer credit grew more slowly to $18.9 \%$ (yoy). Loan disbursements were more directed to the productive sectors.

The payment system implementation as the financial system's infrastructure is an important factor to support the financial system and monetary stability. In addition, the payment system also plays an important role to facilitate economic activity and business. During the first quarter of 2013, the reliability of the payment system infrastructure remained well preserved. This was reflected in the implementation of a secure and smooth payment system. Payment system reliability is indicated by the availability of payment systems in meeting theappropriate service level that has been set. Bank Indonesia is consistently working to improve the performance of the payment system as the lifeblood of Indonesia's economy. This effort has shown good results, with the increasing role of payment systems in supporting economic activity. 